\title{
The perspectives of brazilian homemakers concerning living with type 2 diabetes mellitus
}

\author{
Denise Maria Guerreiro Vieira da Silva ${ }^{1}$ \\ Kathy Hegadoren ${ }^{2}$ \\ Gerri Lasiuk ${ }^{3}$
}

\begin{abstract}
The purpose of this study is to present an understanding of the experience of Brazilian homemakers with type 2 diabetes mellitus (DM2). A descriptive exploratory design was used and semi-structured interviews were conducted with 25 Brazilian homemakers concerning their experience. The interviews were recorded, transcribed, and the resulting text was analyzed using the sequential step method. Data converged to one dominant category, "constructing one's identity in the family context", which is comprised of three categories: gender differences; day-to-day concerns; and incongruity between knowledge and behavior related to DM2. These findings suggest that participants construct their identities within the family context and that their experience of living with DM2 is integral to their self-identification as wives and mothers. This, in turn, has implications for the design and implementation of programs to assist women in managing DM2 effectively.
\end{abstract}

Descriptors: Diabetes Mellitus; Women's Health; Nursing; Families.

\footnotetext{
${ }^{1} \mathrm{PhD}$, Associate Professor, Departamento de Enfermagem, Universidade Federal de Santa Catarina, Brazil.

2 PhD, Full Professor, Faculty of Nursing, University of Alberta, Canada.

${ }^{3} \mathrm{PhD}$, Assistant Professor, Faculty of Nursing, University of Alberta, Canada.
}

\section{Corresponding Author:}

Denise Maria Guerreiro Vieira da Silva

Universidade Federal de Santa Catarina. Departamento de Enfermagem

Rodovia Dr. Antonio Moura Gonzaga, 647, Casa A 19

Bairro: Rio Tavares

CEP: 88048-301 Florianópolis, SC, Brasil

E-mail: denise@ccs.ufsc.br; denise_guerreiro@hotmail.com 


\section{As perspectivas de donas de casa brasileiras sobre a sua experiência com diabetes mellitus tipo 2}

O objetivo deste estudo foi compreender a experiência de donas de casa brasileiras com diabetes mellitus tipo 2 (DM2). Foi utilizada abordagem descritiva exploratória, e entrevistas semiestruturadas foram realizadas com 25 donas de casa, abordando sua experiência com o DM2. As entrevistas foram gravadas, transcritas e o texto resultante foi analisado usando-se o método de etapas sequenciais. Os dados convergiram para um tema dominante construindo sua identidade no contexto da família, composto por três subtemas: diferenças de gênero, preocupações do dia a dia e incongruência, entre conhecimento e comportamento, relacionada ao DM2. Esses achados sugerem que as participantes constroem sua identidade no contexto da família e que a experiência de viver com DM2 é parte integrante de sua identificação como esposa e mãe. Esses resultados têm implicações para o planejamento e a implementação de programas que contribuam para que as mulheres gerenciem seu DM2 de forma eficaz.

Descritores: Diabetes Mellitus; Saúde da Mulher; Enfermagem; Família.

\section{La perspectiva de ama de casa brasileña sobre la vida con diabetes mellitus tipo 2}

El propósito de este estudio es comprender la experiencia de las amas de casa brasileñas con la diabetes mellitus tipo 2 (DM2). Se empleo un abordaje exploratorio descriptivo, donde participaron de las entrevistas 25 amas de casa de Brasil acerca de su experiencia con el DM. Las entrevistas fueron grabadas, transcritas y el texto resultante se analizó mediante el método secuencial de cuatro etapas: aprensión, síntesis, teorización y transferencia. Los datos se reunieron en un tema dominante: "construyendo su identidad en el contexto familiar", que se compone de tres sub-temas: las diferencias de género, las preocupaciones del cotidiano y la incongruencia entre el conocimiento y el comportamiento relacionado con DM2. Estos hallazgos sugieren que los participantes construyen su propia identidad dentro del contexto familiar y que su experiencia de vivir con DM2 es parte integral de su identificación como esposas y madres. Esto, a su vez, tiene implicaciones para el planeamiento e implementación de programas para ayudar a las mujeres para administrar con eficacia la DM2.

Descriptores: Diabetes Mellitus; Salud de la Mujer; Enfermería; Familia.

\section{Introduction}

The challenge of promoting self-care among people with type 2 diabetes mellitus (DM2) has mobilized health care professionals around the world. Even with established clinical guidelines and important advances achieved in knowledge in regard to treatment to obtain better clinical control of the disease, many with DM2 still do not achieve effective glycemic control and remain at risk of long-term complications. Studies comparing men and women with DM2 report that women have worse glycemic control, self-care practices, and quality of life ${ }^{(1-2)}$. Factors associated with these findings reflect the growing recognition that there are different health and illness patterns between men and women, which transcend biology and include psychological, cultural, political, economic, and historical factors ${ }^{(3-5)}$.

Our own clinical experience and evidence from previous studies leads us to conclude that women deal with DM2 differently than do their male counterparts ${ }^{(6-8)}$. Brazilian women, especially homemakers, report significant family interpersonal stress associated with their role as "shock absorbers" in family conflicts, which includes everything from the day-to-day responsibility of caring for family members to mediating family conflicts. Other studies addressing women with DM2 
focus on cultural issues across a number of racial and ethnic groups ${ }^{(9-11)}$. Others examine risk factors associated with the development of DM2(12-13); psychological impact ${ }^{(14-15)}$; family support ${ }^{(9,16)}$; quality of life ${ }^{(17)}$; treatment adherence(18); and metabolic control of DM2(19). There is little information, however, on how women integrate or negotiate DM2 healthrelated demands with the needs of their families. Women, whether they work at home or have a paid job, typically assume the responsibilities of raising children, managing the household, and managing the health care needs of family members ${ }^{(16)}$.

DM2 is a serious health problem, with immediate and long-term consequences for an effected individual's day-to-day life. The World Health Organization's (WHO) (20) recognizes diabetes as a serious global health issue. The main problem associated with living with a chronic disease like DM2 is ongoing maintenance; only $20 \%$ of people adhere to treatment regimes that are prescribed to them. WHO attributes this low adherence rate to a lack of health care services addressing the broad impact associated with living with a chronic disease. It urges nations and health care systems to introduce a multiplicity of measures to limit the longterm consequences of chronic diseases and stresses the importance of tailoring treatment plans to address the unique needs of individuals who live within particular social and geographic environments(20). Because gender is a powerful determinant of health, it is critical to include gender in the development of any measures intended to attenuate the risk of developing complications related to chronic health problems.

The aim of this qualitative study is to present an understanding of the experience of Brazilian homemakers living with DM2 and, specifically, what it is like for them to balance their own health care needs against the needs of their families. From a gender standpoint ${ }^{(21)}$, we engaged in conversational interviews with women addressing their experience of living with and managing DM2.

\section{Method}

A purposive sample of women diagnosed with DM2 was recruited from both an urban tertiary care hospital and a public health clinic in southern Brazil. The selection criteria included self-identification as a homemaker, not being employed outside the home, having children, and having been diagnosed with DM2 for more than two years. Participants ranged from 38 to 82 years old (average age $=61$ years). Most of the women were married or widowed (76\%); had less than eight years of formal education (68\%); and had between one and eight children. Participants had been diagnosed with DM2 two to 38 years prior to participation in the study, with an average of 14.5 years.

Nurses working in the tertiary care hospital and the public health clinic initially contacted the potential participants to explain the study's objective, answer questions, and obtain written consent. A single interview was scheduled with each of the 25 women who consented to participate. Follow-up interviews were conducted with three of the women to clarify parts of the interview or issues that arose during preliminary stages of data analysis. Demographic data were collected through a questionnaire that women completed after the interview.

The semi-structured, conversational interviews were conducted at a location of the participants' choice. Initial questions focused on the women's dayto-day experiences of living with DM2, the contexts of such experiences, and what they valued within these contexts. The interviews were conducted by the primary author or trained research assistants (undergraduate nursing students) and ranged from 20 to 90 minutes in length; the interviews were recorded and later transcribed verbatim.

Data analysis followed a method that involves four sequential processes: apprehension, synthesis, theorization, and transference ${ }^{(22)}$. In the apprehension phase, all of the interviews were read several times to gain a general understanding of their content. During the synthesis phase, the data were coded in two stages: stage 1 was a free flowing summarization ("topic coding") of the verbal content and in stage 2, the most significant codes were selected and organized to form major categories. These four categories express the core content of the interviews and converged to a central theme. In the categorization process, we went beyond the written text and the summary codes, to add interpretive meaning to these codes. We then moved to theorization and transference, elaborating potential meanings for each of the categories while seeking support from or contrast with the related literature. The significant findings were elaborated with direct quotes from the transcripts.

A diary was used to register observations of the primary author and her preliminary reflections during the process of data collection and the preliminary analysis of data. It was also used for the creation and validation of the categories and the central theme. The records in this diary contributed to identifying the situations that needed to be studied in depth and/or receive further clarification, guiding the continuity of 
data collection. One of the situations considered in this process was the inclusion of women with different periods of experience in different stages of their lives, for example, with little and adult children. The primary author manually codified all the transcript interviews and developed the first categorization. This process was subsequently reviewed and refined by the other authors through discussion and reflection concerning whether the interpretation expressed the perception of the women interviewed about being women, housewives and having diabetes.

The research project was approved by the Ethics Committee on Human Research of the Federal University of Santa Catarina, Brazil, number 005/2008, on March 10, 2008. All the participants signed informed consent forms and were informed about their right to withdraw from the study at any time and they all had their right to confidentiality guaranteed.

\section{Results}

Analysis of data converged to the central theme, constructing one's identity in the family context, which represents the manner in which women perceive and interpret their lives and how diabetes is a part of those lives. This theme is composed of three categories: "gender differences"; "day-to-day concerns"; and "incongruity between knowledge and behavior related to diabetes care". These categories are interconnected around the central theme, adding supporting evidence that Brazilian homemakers' experiences of living with DM2 cannot be understood independently of the family context, which shapes their existence.

\section{Perceived Gender Differences}

Being a mother and wife was the central focus of the women's lives. It both shaped their identities and furnished the context of their experience: where they live, with whom they live, and their reasons for living. The women spoke of how being a mother and wife involved the performance of multiple roles that often required submission, self-control, dedication, and suffering. Diabetes did not change these roles, but reinforced some aspects of them, for they always placed family needs first, even when it was detrimental to their own health needs.

The women in the study perceived their lives as more complex and more difficult than the lives of men. Their self-image was, in the majority of cases, negative. They spoke of feeling sad, old, and unmotivated. Two of the women in the study who seemed to have a more positive self-image showed greater acceptance of their diabetes and more active lives, independent of their families. In general, participants believe that women are more stressed and worry more than men. One source of the women's stress is the myriad chores associated with maintaining a home, children, husband, and extended family. This stress is further compounded by the expectation of having everything under control and in harmony. In contrast, they view men as having one chore - their work outside of the home. ... men don't have the work that we have at home... we get upset at any little thing, with the housework... And men don't have to, you know? They don't have to worry about food, ironing, cleaning the house... When I see all the work that needs to be done, I already get upset; I already start to shake... Oh my God, I haven't done this yet, I haven't done that... and that's how I worry about things. (E18)

Other differences between men and women refer to emotional engagement and emotional expressivity. Whereas women are more sensitive towards others and more readily perceive distress in others, the participants describe the men in their lives as selfcentered. When things go wrong, women worry and men direct their energies outward, often becoming aggressive.

The women also spoke of having to severely limit what they eat to avoid gaining weight and raising their blood glucose levels; in contrast, they believe that men with diabetes can eat anything they like without altering their glucose levels. Husbands and brothers with diabetes were more able to control the disease, seeming to require less effort than women to do so. Women are more stressed. Because the woman has to take care of the house, have kids, have a job, and then have to pay the bills... many other things that a woman has to do, as well. I buy everything for the home. So arriving at home, the children and grandchildren have to study, to do the laundry, take care of the food, and take care of the husband. He leaves for work in the morning and arrives only after dark. So by the time he arrives, everything must be washed and ironed. So women stress themselves more than men. (...) My husband ate and ate and he still had diabetes, he had diabetes and he still ate. If I made sweet rice, he would say it was the best. (E6)

Although these perceived gender differences were seen as unfair and as placing women at a disadvantage in relation to men, the women passively accept the situation as part of their social role. 


\section{Day-to-day Concerns and Worries}

In this study, 'concerns' refer to situations, events, or individuals that require the women's special attention. Through their worry, the women emotionally invest themselves in these concerns, as if ruminating on them could prevent something from going wrong. The concerns did not always involve action; rather they seemed to involve anticipation of future suffering or a potential threat to safety and/or well-being. If the concern persisted or if a woman did not have the necessary internal resources or social support to manage her distress, it often interfered with control of the disease. The women's concerns and worries were concentrated around two major issues - the safety of her extended family and health. Thinking and worrying about what might or could happen was so pervasive that it could fill their days.

The women's primary concerns stemmed from the family, while worry about their own health was secondary. Their worry about their family's safety and well-being was so intense, in many instances it became hyper vigilance. As an example, a child being a few minutes late returning home from work was reason to be concerned. I'm very attached to my children... my family. (...) Because we have that worry about our children, that they won't get mixed up in something or whatever, but my father was run over and died because of drinking, you know? So it leads you to that overwhelming thought... and $C$. has already been in two accidents because of drinking and I've got another youngest who I've raised... not just raised, because he's my grandson, so we're blood... So this $C$. is 33 years old and he's single and he's the one I worry about... there's always that worry. (E1)

The women's concerns about their health, particularly those related to diabetes, were always in the background. They thought and worried about potential complications, monitoring their blood glucose, their diet, and the use of medication, such as insulin. The main concern about complications was the possibility of blindness. Stories of people with diabetes who had gone blind and one woman's growing loss of visual acuity evoked such strong emotion that it often catapulted worry into outright fear.

Monitoring glucose was a particular concern, especially for those who depended on the Brazilian public health care system. In these instances, the women's concern did not focus on the results of glucose testing per se, but rather on the operational aspects of having to go to a health unit for testing, having to wait in line, and the need to fast, which many times induced hypoglycemia.

While nutrition and feeding the family are central in Brazilian women's role, these activities are a particular concern for women who live with diabetes. Many felt unsure about how to deal with diabetic restrictions and spoke of having exaggerated hunger and constantly battling with the desire to eat forbidden foods. Some were very concerned over the degree to which their dietary restrictions interfered with their family's nutrition and eating. These women were adamant that their family should not be deprived of anything on their account.

Some of the women interpreted the need for daily insulin injections as a sign of the severity of their diabetes. When controlling their blood glucose became difficult and their physician informed them of this possibility, they became very concerned. It was as if, at that point, there was no turning away from the disease. Other women insisted that diabetes was not a concern for them, explaining that diabetes was something to which they had already become accustomed, as various people in their family had also become accustomed. For the latter, diabetes had become part of life, a consequence of aging. However, this did not necessarily translate into managing their diabetes well, in terms of ongoing self-care and adherence to treatment. In many instances, this acceptance had the opposite effect, as the women minimized the significance of their condition. I'm not worried, if the doctor says that yes, I have this problem, I'm not worried! Between one thing or another, we're all going to die, right? Sometimes it could be from this and I'm going to die from something else, you know, we never know. So, I don't worry. (...) What else worries me? Oh, when we know, when we find out someone's sick, you know, from the family, something like that. Then I worry. (...) I just wonder about altered diabetes, so if I eat something sweet, today I already ate something sweet... I think that's why it was higher... and these exams leave me so anxious! (E3)

\section{Incongruity between knowledge and behavior related to diabetes care}

Even when women accepted their diabetes as something that requires ongoing management and treatment, there was little evidence that they had made any significant lifestyle changes to manage it. On receiving the diagnosis, the women became worried, upset, or irritated; few made serious efforts to change 
personal habits or routines. It was as if the initial emotional impact was attenuated by the lack of obvious life threatening symptoms and the belief that their day-to-day lives would remain relatively unaltered. The women who did alter their dietary intake did not maintain the changes and soon reverted back to their former patterns. These women either minimized the possibility of serious health problems over time or accepted the situation as inevitable.

As the years passed (between two and ten years) and DM2-related problems began emerging (e.g., infections, polyuria, vision impairment, and even peripheral circulatory problems that resulted in amputations), the women were forced to rethink issues related to self-care and treatment adherence. In these instances, diabetes became a stimulus for change only when serious complications developed and the women could no longer ignore them. Even women who have family members with diabetic complications (e.g., amputations, blindness, death) maintained the belief that their own diabetes was fundamentally different. These women looked for and emphasized differences between their own experiences and those of others. They operated from the notion that the longitudinal course of the disease, response to treatment, and the potential for related health problems were unique to each person. This allowed them to dismiss or minimize others' experiences and advice, including the experiences of family members with diabetes and the advice of health professionals.

Accepting dietary restrictions presented the greatest challenge for the women, because food and cooking were a source of great pleasure, as well as being evidence of their success as homemakers. The women's feelings about this ranged from passing irritation to anger to anxiety when they felt deprived of something or a family member interfered with their food choices or prohibited certain foods. But mostly the women spoke of sadness that was with them always. Living with diabetes was perceived primarily in relation to the imposed food restrictions and as a disease without a cure. What disappoints me so much is when I go to the supermarket. (laughter) There's everything that you can't eat; those cakes, those pies that you make with caramelized sugar... oh, that is really my favorite, how do you say it? More ... disappointed. It's day and night - sometimes I wake up and I say, "Aw... man... I have to take an injection," and a pill and then make these foods that have nothing in them! (E24)

Attending parties and other social events were chronic sources of conflict for the women. If they did participate in these social events, they would eat cakes and other restricted foods, only later acknowledging the repercussions doing so had on their glycemia. Although not participating in social events was an option, the women felt it would exclude them from sharing moments of happiness and marking important family occasions. Sometimes the women "would eat while hiding" away from their family members. Eating behaviors evoked ambivalence for many of the women. Some reported pride when they were able to maintain a certain control over themselves; for these women, eating or not was their decision. Others felt the happiest when family members controlled their food intake, as it was a way of receiving attention.

The women's testimonies reflected a continuous tension between following their prescribed diet and rejecting the diet. Many times they reported that they adhered to their food plan, only to acknowledge a few minutes later that they did not. While the women seemed to understand the need for it and the various elements of their diet, they did not feel compelled to consistently follow it. In reality, the diet was more part of a discourse about recognizing limits, expressing dissatisfaction, and showing themselves as people with problems. It seemed that the very idea of having dietary restrictions was sufficient to make them feel "tortured". While they did not actually adhere to the diet, it existed as a personal limit against which they had to fight and rebel. In this way, they constantly pondered the risks and benefits in relation to changes in their body weight. However, when diabetic complications were more apparent and immediate, they would more readily accept their prescribed diet. However, if the imposition of dietary restrictions "spoke louder to them" they sought other strategies to rationalize their poorer dietary choices. The problem is that diabetes brings me great anxiety, makes me want eat something; it's like a pregnant woman! I cannot rest while I don't eat. So, the diabetes does it to me, makes me very hungry and I can't eat ... I suffer from this.

Exercise was not part of these women's lives. Doing household chores was considered sufficient exercise. When they did attempt to do the recommended exercises, they complained of feeling very tired and stated that exercises were meant for those who did not have to keep a house.

\section{Discussion}

This study reveals the experience of Brazilian homemakers concerning living with DM2 and how their 
identities as women and the experience of DM2 is shaped by their role(s) within the family. The findings highlight that while the women recognize DM2 as a chronic disease, which forbids certain pleasures and results in long-term health concerns, they subordinate their own needs to those of their families.

The central theme, constructing one's identity in a family context, suggests that these homemakers recognize themselves first as mothers/wives and that self-expression is limited to what is perceived as acceptable within the family context. Their main commitment is to maintain their family as united and healthy, remaining vigilant to threats that may arise to challenge their efforts in this regard. In safeguarding family health and well-being, the women seek to keep everyone close and remain alert to, concerned with, and involved with all aspects of their families, particularly their children. In the construction of this identity, they recognize that there are multiple activities and they accept (some more reluctantly than others) their life condition as subordinate to the needs of their children and husbands, something they see as related to being female. This is evident when their daughters take over their duties and responsibilities when they are no longer able to fulfill them ${ }^{(17)}$. Despite societal changes in Brazil, the traditional family model remains strong, especially among women who do not work outside their homes.

Concerns with controlling diabetes and dissonance between what they know to be necessary to control the disease and what they actually do are important factors related to how DM2 is integrated into their daily lifestyles ${ }^{(13-14)}$. Decisions regarding adherence to dietary restrictions and other care components are highly variable and depend on the immediate situation and how the women rationalize their choices(23). Even though they recognize that they have a chronic and incurable disease, many believe that there will always be time in the future to adhere to their prescribed treatment, especially concerning their diet. Postponing was a frequent coping strategy, because ensuring that treatment did not alter their family's daily routines had higher priority than did their own health behaviors. Concerns about the longitudinal course of their disease and the required multi-modal treatments were overridden by more immediate concerns that strict adherence would have a negative impact on family routines, thus making it very difficult to maintain a consistent and healthy approach to DM2 care(10).

The belief that family needs come before their own and that diabetes management is lower down on their priorities does not mean that the women outright dismissed having diabetes. The women lived in a daily state of ambivalence - sometimes acknowledging the severity of DM2 and following their prescribed treatment regime and other times minimizing their condition and its possible consequences. Worries about their family's needs or despair about not participating in celebrations and social events were issue that distracted them from their own health. On the other hand, recognition of a sign or symptom of the seriousness of diabetes made them consider the importance of adherence to their prescribed treatment, but did not necessarily motivate them to action. Ambivalence was found in another study with people with DM2(24), many of whom frame eating 'good food' in terms of enjoyment and taste rather than food that helps them to achieve glycemic control. These different orientations go beyond simple decisions about eating particular foods or not, and are inextricably linked to habits and routines, pleasure and relationships. Findings from this study also suggest that Brazilian homemakers' food choices are also influenced by their perceptions about what is good for their families.

\section{Final Considerations}

This study reaffirms the importance of family inclusion in health care practice and teaching and that of understanding the complex roles women play within the family as the basis for individualized diabetes teaching. Broader improvements in the metabolic control of diabetes and living more healthy lives for these women will require considering supporting women such that priority is given to their health needs. The women, then, need to discuss those needs with their families, negotiating priorities, and constructing new opportunities for incorporating their health needs into the daily routine of the entire family. The findings also highlight the need for the health team to support the health needs of women with DM2. Complementary expertise in endocrinology, social determinants of health (age, gender, gender roles and socioeconomic status), and chronic disease management within a selfcare model are all necessary components of a successful diabetes management service for women.

One potential strategy that shows significant promise is the creation of support groups that allow women to share their experiences. In these groups, sharing strategies to negotiate health needs in the context of the family among those with similar circumstances provides both social support and key information to better manage one's diabetes. In addition 
to this, in-home individualized health education with the whole family is needed. Enhancing women's ability to successfully self-manage their diabetes and minimize the risk of long-term health problems requires establishing and maintaining a trusting relationship with health care providers who acknowledge the fundamental role of the family in framing their daily lives. Given the seriousness of the consequences of poor glycemic control over time and the overrepresentation of women among those with complications from DM2, it is imperative that issues of gender and gender roles be incorporated into care planning and educational programs.

\section{References}

1. McCollum M, Hansen LB, Lu L, Sullivan P. Gender differences in diabetes mellitus and effects on self-care activity. Gender Medicine. 2005;2(4):246-54.

2. Whithemore R, Melkus GDE, Grey M. Self-report of depressed mood and depression in women with type 2 diabetes. Issues Mental Health Nurs. 2004;25(3): 243-60.

3. Aghard EE, Ahlbom A, Andersson T, Efendic S, Grill $V$, Hallqvist $\mathrm{J}$, et al. Explanations of socioeconomic differences in excess risk of type 2 diabetes in Swedish men and women. Diabetes Care. 2004;27(3):716-21.

4. Lasuik GC, Hegadoren K M. Posttraumatic stress disorder part II: Development of the construct within the North American psychiatric taxonomy. Perspect Psychiatr Care. 2006;42(2):72-81.

5. Samuel-Hodge CD, Feadem SW, Skelly $A H$, Ingram $A F$, Keyserling TG, Jackson EJ, et al. Influences on day-today self-management of type 2 diabetes among AfricanAmerican women. Diabetes Care. 2000;23(7):928-33.

6. Silva DMGV, Francioni FF. The process of accept life with diabetes mellitus: Considering the influence of the environment. People with diabetes mellitus: Choices of healthcare and treatment. Texto Contexto Enferm. 2002;11(3):36-43.

7. Mattosinho MMS, Silva DMGV. Therapeutic itinerary of the family and adolescent with type 1 mellitus diabetes. Rev. Latino-Am. Enfermagem. [periódico na Internet]. dez 2007 [acesso 26 nov 2008]; 15(6):1113-9. Disponível em: http://www. scielo.br/scielo.php?script=sci_arttext \&pid=S0104$11692007000600009 \&$ Ing $=$ pt. http://dx.doi. org/10.1590/S0104-11692007000600009.

8. Silva DGV, Francioni FF, Souza SS, Mattosinho MMS, Coelho MS, Sandoval RCBruno et al. Pessoas com Diabetes Mellitus: suas escolhas de cuidados e tratamentos. Rev Bras Enferm. [periódico na Internet]. jun 2006 [acesso 26 nov 2008]; 59(3):297-302. Disponível em: http://www.
scielo.br/scielo.php?script=sci_arttext\&pid=S0034$71672006000300009 \&$ Ing $=$ pt.

http://dx.doi. org/10.1590/S0034-71672006000300009.

9. Burns D, Skelly AH. African American women with type 2 diabetes: Meeting the daily challenges of selfcare. J Multicultural Nurs Health. 2005;11(3):6-10.

10. Kakanovic R, Manderson L. Social support and self-management of type 2 diabetes among immigrant Australian women. Chronic Illness. 2006; 2(4): 291-301.

11. McEwen MM, Bair M, Pasvogel A, Gallegos G. Health-illness transition experiences among Mexican immigrant women with diabetes. Fam Commun Health. 2007;30(3):201-12.

12. Lidfeldt J, Nerbrand C, Samsioe G, Agardh CD. Women living alone have an increased risk to develop Diabetes, which is explained mainly by lifestyle factor. Diabetes Care. 2005;28(10):2531-6.

13. Norberg M, Stenlund H, Lindahl B, Anderson C, Eriksson JW, Weinehall L. Work stress and low emotional support is associated with increased risk of future type 2 diabetes in women. Diabetes Res Clin Pract. 2007;76(3):368-77.

14. Penckofer S, Ferrans CE, Velsor-Friedrich B, Savoy $\mathrm{S}$. The psychological impact of living with diabetes. Diabetes Educ. 2007;33(4):680-90.

15. Tuncay T, Musabak I, Gok DE, Kutlu M. The relationship between anxiety, coping strategies and characteristics of patients with diabetes. Health Qual Life Outcomes. 2008;6:79-87.

16. Heath JA, Bourne WD. Husbands and housework: Parity or parody? Soc Sci Q. 1995;76(1):195-202.

17. Unden $A L$, Elofsson $S$, Andreasson A, Hillered $E$, Eriksson I, Brismar K. Gender differences in self-rated health, quality of life, quality of care and metabolic control in patients with diabetes. Gender Med. 2007; 5(2): 162-80.

18. Vermeire $E$, Hearnshaw $H$, Ratsep A, Levasseur $G$, Petek D, Dam $H$, et al. Obstacles to adherence in living with type 2 diabetes: An international qualitative study using meta-ethnography. Prim Care Diabetes. 2007;1(1):25-33.

19. Albright TL, Parchman M, Burge SK. Predictors of self-care behavior in adults with type 2 diabetes: An RRNeST study. Fam Med. 2001;33(5):354-60.

20. World Health Organization. Innovative care for chronic condition: Building blocks for action. Global Report. 2002. [acesso 26 nov 2008]; WHO/MNC/ $\mathrm{CCH} / 02.01$. Disponível em: http://www.who.int/ diabetesactiononline/about/icccglobalreport.pdf.

21. Campbell R, Wasco SM. Feminist approaches to social science: epistemological and methodological 
tenets. Am J Commun Psychol. 2000;28(2):773-91.

22. Trentini M, Paim L. Pesquisa convergente assistencial. Florianópolis: Insular; 2004. 141 p.

23. Péres DS, Franco LJ, Santos MA, Zanetti ML. Social representations of low-income diabetic women according to the health-disease process. Rev. LatinoAm. Enfermagem. [periódico na Internet]. 2008 June [acesso 20 julho 2011]; 16(3):389-95. Disponível em: $\quad$ http://www.scielo.br/scielo.php?script $=s c i$ arttext\&pid $=$ S0104-11692008000300009\&Ing=en. h t t p : / / d x.doi . org/10.1590/S0104 11692008000300009.

24. Broom D, Whittaker A. Controlling diabetes, controlling diabetics: Moral language in the management of diabetes type 2. Soc Sci Med. 2004;58(11):2371-82. 